論 文

\title{
アクティブ・サーモグラフィ法による乳ガン検査の可能性の検討
}

\author{
非会員 尹 鍾 賢 (秋田大学) 非会員 水戸部一孝（秋田大学） 非会員 片 寄＼cjkstart喜 久（秋田大学） \\ 非会員 小川 純一（秋田大学） 正会員 吉 村＼cjkstart昇（秋田大学）
}

\section{Possible Application of Active Thermography in Breast Cancer Inspection}

Non Member Jonghyun Yoon(Akita University), Non Member Kazutaka Mitobe(Akita University), Non Member Yoshihisa

Katayose(Akita University), Non Member Jun-ichi Ogawa(Akita University) and Member Noboru Yoshimura(Akita University)

\begin{abstract}
We manufactured a far infrared ray (FIR) heater that uses natural zeolite as the radiation body, and conducted active thermography to heat the body surface with this FIR heater. We also evaluated the possible application for breast cancer inspection by examining eight subjects with breast cancer using this system. From the results of the thermal image and histogram analysis, we found that the temperature of the tumor region was higher than the normal tissue region in six out of eight subjects just before heating, and after heating for 1 or 2 minutes. Also, the $\mathrm{d} T \mathrm{~s} / \mathrm{d}$ Tr property was different from the tumor and blood vessel regions after heating for 1 or 2 minutes. This may become an important criterion in discriminating between tumor and blood vessel regions automatically in thermal images.
\end{abstract}

KEYWORDS : FIR heater, active thermography, breast cancer, natural zeolite

\section{1. まえがき}

人体の解剖的な構造の異常の有無を診断する X-線マンモグラフ イに対して,サーモグラフィは放射線で被曝することなく生体の機 能的な情報を収集できると考えられ, 近年その価值が見直されて いる. 乳ガン (breast cancer) 検查へのサーモグラフィの利用は古 く, 1956 年 Lawson らにより悪性腫瘍が他の組織より温度が高いこ とを拠り所に皮膚温度の違いに基づく乳ガン検查を実施して以来, サーマルカメラを用いた多くの検査法が試みられ, 正診率改善の 努力が続けられてきた.

Keyserlingk ら ${ }^{1)}$ は乳癌検查においてマンモグラフィにサーモグ ラフィを加えることにより, 正診率が 10\%向上したと報告してい る. Ohasi と $\mathrm{Uchida}^{2}$ は体表面を強制的に冷却し, 体温が上昇する 過程を比較してその差分画像を作る手法 (dynamic thermography)に より, 乳癌の正診率が $54 \%$ から $82 \%$ まで向上されたと報告している. また, Anbar ら ${ }^{3)}$ は, 悪性腫瘍細胞 (malignant cells) から生じる一 酸化窒素 $(\mathrm{NO})$ により生体組織の温度変化の減衰量に差が生じる現 象を科学的根拠として, 高感度, 高時間分解能赤外線撮影システ ムを用いて体表面の温度変化を計測し, FFT により周期的な温度変 化を画像化して乳癌の存在を検出するDAT (dynamic area telethermometry) 技術を開発している.

生体組織の熱伝導率はその部位によって顕著に異なり, 脂肪組 織では $0.0005 \mathrm{cal} /\left(\mathrm{s} \cdot \mathrm{cm}^{2} \cdot{ }^{\circ} \mathrm{C}\right)$, 筋組織では $0.001 \mathrm{cal} /\left(\mathrm{s} \cdot \mathrm{cm}^{2} \cdot{ }^{\circ} \mathrm{C}\right)$, 直径 $0.1 \mathrm{~mm}$ 程度の血管を流れる血流で $0.24 \mathrm{cal} /\left(\mathrm{s} \cdot \mathrm{cm}^{2} \cdot{ }^{\circ} \mathrm{C}\right)$ である ${ }^{4)}$. 生体加熱に関寸る過去の研究において, 遠赤外線 (FIR) による
輻射加熱では, 熱伝導および温風による対流熱伝達加熱と比べ血 管の拡張が少ないため，加熱停止後でも組織に熱が蓄熱しやす い(保温性が高い) ことが報告されている5）6）。我々は従来のサ 一モグラフィ検查に遠赤外線（Far infrared ray：FIR）による 加熱プロセスを加えることで能動的に体表面の温度をコントロ ールし, 各生体組織の昇温特性の違いに基づき, 腫瘍部, 腫瘍 部周辺の血管部および正常組織部を弁別できないか検討してき た ${ }^{7)}$. 従来のサーモグラフィは身体の温度が室温と平衡した状態 で受動的 (passive) に測定する検查方法であるのに対して, 本論 文で試みる手法は体表面を能動的 (active) に冷却・加熱して過渡 的な温度変化を測定する検査方法であり，これをアクティブ・サ 一モグラフィ(active thermography) と定義する.

本論文では, 昇温時の熱損失が少ない FIR による体表面を加熱 する方法を採用し, FIR ヒータとサーマルカメラを組み合わせた アクティブ・サーモグラフィ検査システムを構築し, 8 名の乳ガ ン患者のボランティアを対象として検査を実施する.さらに, 得られた熱画像検査データから腫瘍 部 (malignancy), 腫瘍部周 辺の血管部 (blood vesse1), 腫瘍部と左右対称の位置にある正 常組織部 (normal tissue)における熱パターンの変化を観察し, 本手法による乳癌検査の可能性を検討する.

\section{FIR 放射体ヒータの作製}

FIR 放射体の作製方法について述べる，本論文では，過去の研 究で遠赤外線放射特性に優れていた秋田県二ツ井町産の天然ゼ オライトとパーライトを放射体の原材料として使用した. ゼオ 
ライトは $1100^{\circ} \mathrm{C}$ で 1 時間焼成した後, 粒径 $5 \mu \mathrm{m}$ 以下の粉末状に粉砕 し, ゼオライトとパーライトが $2.0: 1.0$ の重量比となる様に混合 した。 なお, 試料を放射体として固定するため, 試料とバインダ 一(アロンセラミック D)が 1.0：0.67 の重量比となるように混合し てペースト状に加工した後, 基板であるセラミックスボードに塗 布した.

図 1 はペースト状試料をヒータに塗布する前後の写真を示す. セ ラミックスボード（縦 $12 \mathrm{~cm} \times$ 横 $8 \mathrm{~cm} \times$ 厚さ $0.7 \mathrm{~cm}$ ）を 6 枚並列に 固定し, 放射体を均一に加熱するために, 図 1 (a) に示すように直 径 $0.45 \mathrm{~mm}$, 抵抗率 $6.79 \Omega \cdot \mathrm{m}$, 長さ $2.8 \mathrm{~m}$ のニクロム線を配置し，そ の上に図 1 (b)のようにペースト試料を塗布した後, 常温で 24 時間 乾燥させて放射体ヒータを作製した.

過渡的な体表面の温度変化情報を得るために加熱過程で 2 度の加 熱停止期間を設定しており，FIR 放射体から放射される遠赤外線を 素早く $0 \mathrm{~N} / \mathrm{OFF}$ できるように FIR 放射体と加熱対象の間にシャッタ 一を設置して, 開閉操作が可能なヒータ機構を構成した. 図 2 に FIR 放射ヒータ機構の構成を示寸. 図 2 (a)に FIR 放射ヒー夕機構の 正面図, 同図 (b)に側面図を示寸. 図 2 (b) において, 4 つの円は直 径 $30 \mathrm{~mm}$ のアルミ製のシャフトを示している. 後方下部のシャフト にはモータが連結されており，4本のシャフトはタイミングベル 卜で連結されているためモータに同期して回転することができる. タイミングベルトにはアルミ製の遮光シートが取り付けられてお り, 遮光シートの位置を変えることでFIR 放射体から放射される遠 赤外線を遮断 (シャッター $\mathrm{ON}$ ) ・照射（シャッター $\mathrm{OFF}$ )することがで き，シャッターとしての機能を実現した．なお，検查中にFIR 放射 体が破損して加熱された破片が被験者に落ちる危険を避けるため に, FIR 放射体は上向きに設置しており, ステンレス板を鏡面状に 研磨した反射鏡（Reflector）で遠赤外線を反射させることで遠赤 外線の方向を変え, ベッドに仰臥した患者を照射する構造とした.

\section{3. 検査手順および方法}

検查手順を説明する. 赤外線サーマルカメラ (TVS 620:AVI0)によ る検查時間はおよそ 35 分であり, その間被験者には上衣を脱衣し た状態で仰臥姿勢を保ち，できるだけ動かないように教示した。 脱衣直後から被験者の体温と室温が平衡状態に達するまで約 5 分間 待機した後, 送風機により 5 分間体表面を強制冷却し, 再度, 体温 と室温が平衡状態に達するまで 5 分間待機した. その後, FIR ヒー タで 8 分間加熱 (1 分加熱, 30 秒加熱停止, 1 分過熱, 30 秒加熱停 止, 6 分加熱) し, 加熱停止後は体表面が冷えるまでの過程を 8 分間 測定した。

図 3 に検查風景を示す. FIR ヒータは被験者の胸部から $15 \mathrm{~cm}$ 上方 に配置しており，サーマルカメラは被験者の頭部側に設置した. そのため, 熱画像は上下反転した画像となる. 胸部の熱画像は 30 秒あたり 1フレームで測定され，コンパクトフラッシュメディアに 保存された。 また, サーマルカメラはディジタルビデオカメラ (DCR PC-110:SONY) に接続しており, リアルタイム (30 枚/秒)に NTSC 信号で記録された。

\section{4. 結果および考察}

表 1 に被験者 8 名の背景を示す. 腫瘍の位置とサイズは事前にマ ンモグラフィと超音波検査により医師が計測したものであり, 病 期および組織型の情報と併せて表 1 に記した。 そのサイズ計測の 精度は $0.1 \mathrm{~cm}$ である. 病期 I は 1 名, 病期 II a は 5 名, 病期 II b は 1

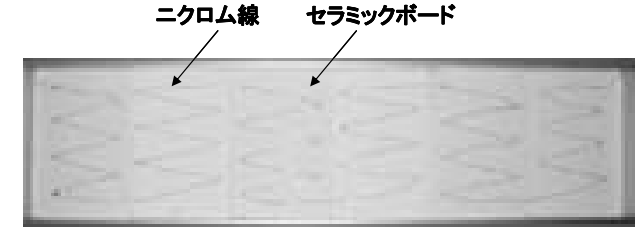

(a) ペースト試料の塗布前

(a) Before application of the paste sample.

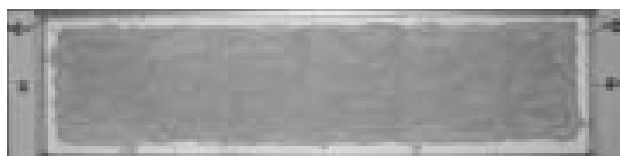

(b) ペースト試料の塗布後

(b) After application of the paste sample.

図 1 FIR ヒータのペースト試料の塗布前後

Fig.1 Before and after application of the paste sample of FIR heater.

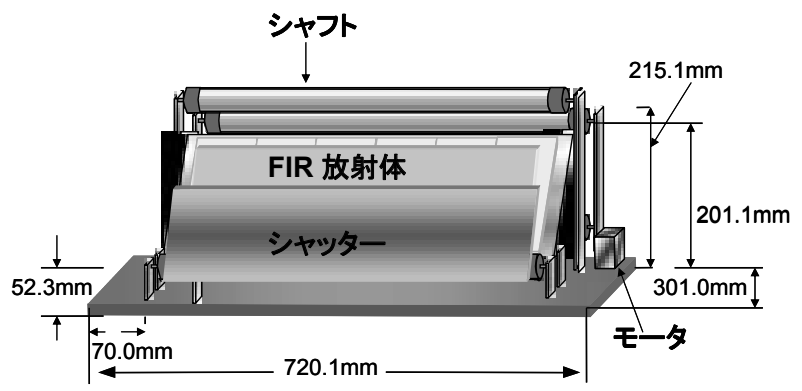

(a) 正面図

(a) Front view.

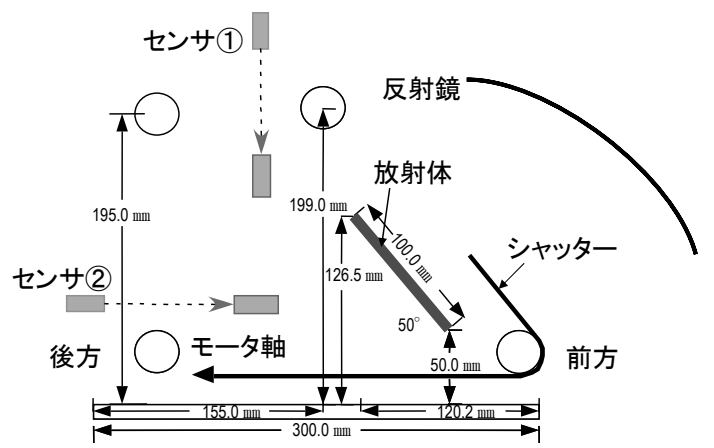

(b) 側面図

(b) Side view.

図 2 シャッターの閉鎖中の FIR ヒータ機構の正面図と側面図

Fig.2 Front and side view of FIR heater apparatus under closing of shutter. 
名, 病期 IIII は 1 名であり, 組織型は乳頭腺管癌 2 名, 硬癌と非浸 潤性乳管癌が各々 1 名, 充実腺管癌が 4 名であった. 一方, 本サー マルカメラで撮影される熱画像の空間分解能はカメラと被験者の 距離で決まり, 今回の検查条件ではカメラと被験者の距離は約 $80 \mathrm{~cm}$ であり, 約 $1.2 \mathrm{~mm}^{2}$ の空間分解能が得られた. カメラを被験者 に近づけることで空間分解能をあげることが可能であり, 将来的 には測定部位だけをクローズアップして撮影することも検討して いる. しかし, 体表面での熱の拡散もあるので, 現時点では 1. $2 \mathrm{~mm}^{2}$ 程度の空間分解能まであれば十分と考えられる.

図 4 に熱画像の一例を示す．検査中にサーマルカメラは被験者の 頭の上部に配置されるから, 熱画像は上下反転されて撮影された. サーモグラフィ検查前医師が腫瘍の位置（右胸部の円環）を金属線 でマーキングしており，医師によりマーキングされたリング内を 腫瘍部位 (malignancy：点 A), 腫瘍の周りに見られる温度の高い線 状の部位を血管部位 (blood vessel : 点 B), そして, 腫瘍部位と左 右対称の位置にある部位（ただし, 血管状の温度の高い部位は避け る）を正常組織として選択して解析対象とした. 検查に用いられた サーマルカメラの最小温度分解能は $0.1^{\circ} \mathrm{C}$ 以下である.

図 5 に図 4 の各点における温度の経時変化を示す. 図4(あるいは 図5)の被験者は表 1 の被験者 4 の熱画像であり, 検查中の体動とサ ーマルカメラのノイズによる細かな変動を取り除き結果の精度と 信頼性を高めるため, 前処理として測定点近傍の約 140 画素で空間 平均を行った. 横軸が経過時間, 縦軸が表面温度を示す. それぞ れのグラフは凡例に示す各測定部位における温度である. 測定を 始めてからの 5 分間（脱衣直後）は腫瘍部位および血管部が正常組 織部位と比べ温度が高いこと, 強制冷却後の 10 分から 15 分の間は 冷却により収縮した血管が膨張することで急に血流が増加するた め, 正常部位と比べ腫瘍部および血管部の温度が高くなっている ことがわかる. 一方, FIR 加熱中には血管部の温度が急激に上昇 し, 腫瘍部および正常組織との温度差が拡大寸ることがわかる.

全ての熱画像は 1 回の検査結果であり, 入院してから手術まで 十分な時間が無いため, 現時点では同一の被験者に対して複数回 測定することはできていない. しかしながら, 熱画像（図 4）の再 現性については，(表面温度は周囲の温度と体の状態によって変動 するが）ヒトの体内の血管や脂肪の配置が短期間で変わることはな いため, 体を一定温度まで泠却した後の熱画像は個人に固有のも のであり，再現性は高いと考えている.

図 6 に加熱直前における各被験者の熱画像を示す. 円環は腫瘍部 位を示している. 加熱直前の熱画像の左右温度パターンを比較す ると, 被験者 1 と被験者 3 を除く 6 例は左右温度パターンに違いが あり, 腫瘍がある体側の温度が高いことがわかる. 腫瘍部周辺に 血管が新生されることで流入出する血流が豊富となり, それに繋 がる体表面付近の血管の温度が上昇した結果, 腫瘍のある体側の 温度が高くなったと考える。

図 7 に加熱 1 分後における各被験者の熱画像を示す. 加熱直前と 比べ体表面の温度が全体的に上昇しており, 加熱後も腫瘍側が正 常側より温度が高く, 腫瘍部周辺の血管の温度が上昇しているこ とがわかる。これは暖められた周囲組織の血液が血管に流入され るため, 腫瘍部周辺の血管の温度が短時間に上昇したためと考え られる。一方，図 6 の結果と同様に被験者 1 と被験者 3 には左右温 度パターンの違いがない. 被験者 1 は病期 I のため腫瘍の進行度が 遅く, 腫瘍のサイズも小さいため, 栄養血管は新生されていないと 考えられ, その結果, 熱画像には左右差が現れなかったと考えら れる. 被験者 3 の場合は 2 つの原因が考えられる. 1 つ目の原因と

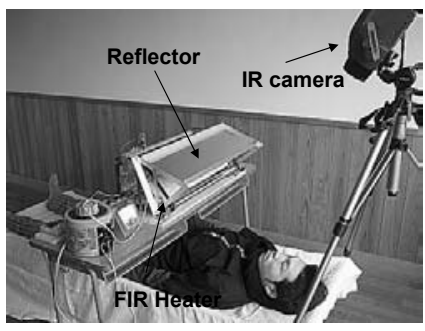

\section{図 3 検査風景}

Fig. 3 Inspection scene.

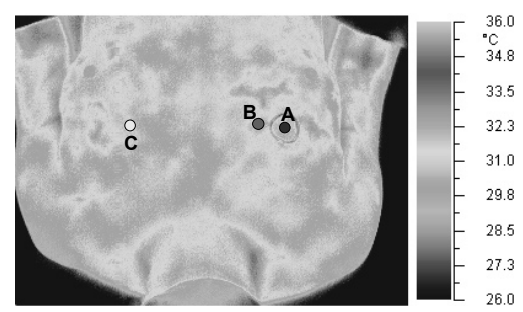

図 4 熱画像の一例 (点 A: 腫瘍部位, 点 $\mathrm{B}$ : 血管部位, 点 $\mathrm{C}$ : 正常組織部 位)

Fig.4 Example of thermal image(Point $A$ : malignancy region, Point $\mathrm{B}$ : blood vessel region, Point $\mathrm{C}$ : normal tissue region).

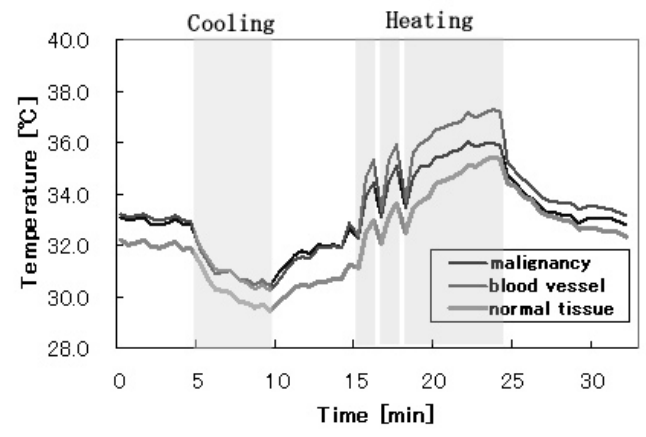

図 5 温度の経時変化

Fig. 5 Trend graph of region.

\section{表 1 被験者の背景}

Table 1 Background of subject.

\begin{tabular}{|r|c|c|c|}
\hline 被験者 & $\begin{array}{c}\text { 腫瘍のサイズ } \\
(\text { 横 } \times \text { 縦 } \times \text { 深さ }[\mathrm{cm}]\end{array}$ & 病期 & 組織型 \\
\hline 被験者 1 & $0.9 \times 0.9 \times 0.7$ & $\mathrm{I}$ & 乳頭腺管癌 \\
\hline 被験者 2 & $2.4 \times 2.3 \times 1.8$ & II a & 硬癌 \\
\hline 被験者 3 & $1.7 \times 1.7 \times 1.5$ & II a & 非浸潤性乳管癌 \\
\hline 被験者 4 & $1.8 \times 1.7 \times 1.5$ & II a & 充実腺管癌 \\
\hline 被験者 5 & $2.5 \times 2.5 \times 1.6$ & II a & 充実腺管癌 \\
\hline 被験者 6 & $2.1 \times 1.7 \times 1.5$ & II a & 充実腺管癌 \\
\hline 被験者 7 & $2.0 \times 1.7 \times 1.7$ & II b & 乳頭腺管癌 \\
\hline 被験者 8 & $3.0 \times 3.0 \times 2.0$ & III a & 充実腺管癌 \\
\hline
\end{tabular}




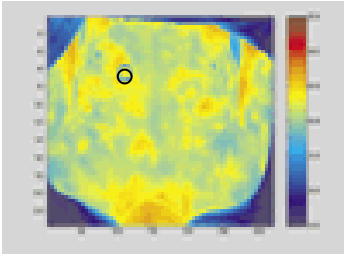

(a) 被験者 1

(a) Subject 1

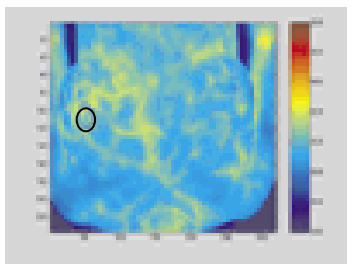

(e) 被験者 5

(e) Subject 5

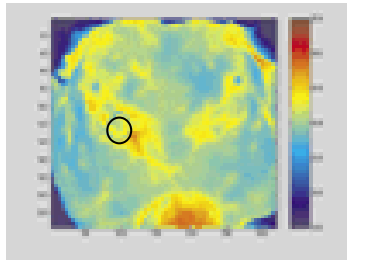

(b) 被験者 2

(b) Subject 2

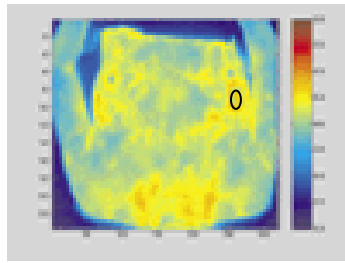

(f) 被験者 6

(f) Subject 6

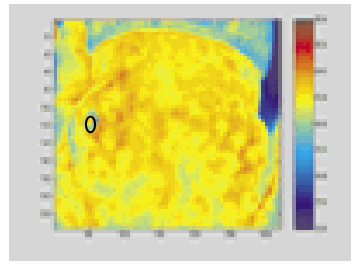

(c) 被験者 3

(c) Subject 3

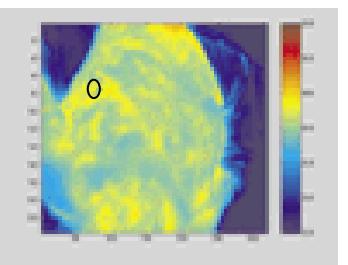

(g) 被験者 7

(g) Subject 7

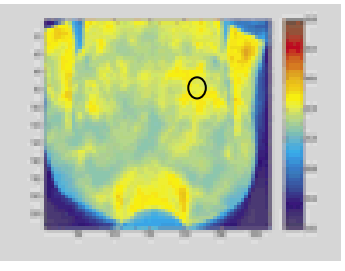

(d) 被験者 4

図 6 加熱直前の各被験者の熱画像

Fig.6 IR image of subjects just before heating.

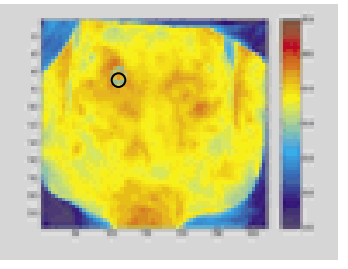

(a) 被験者 1

(a) Subject 1

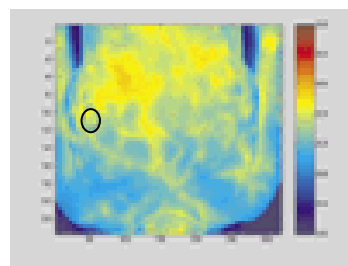

(e) 被験者 5

(e) Subject 5

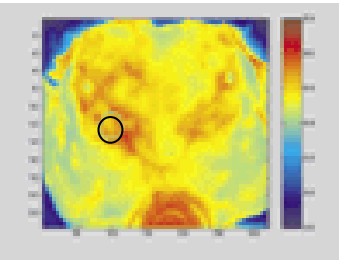

(b) 被験者 2

(b) Subject 2

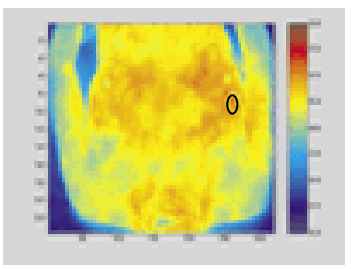

(f) 被験者 6

(f) Subject 6

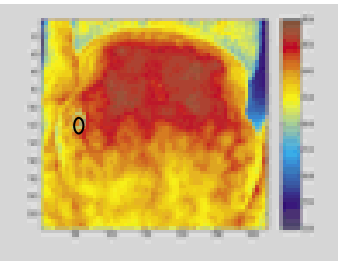

(c) 被験者 3

(c) Subject 3

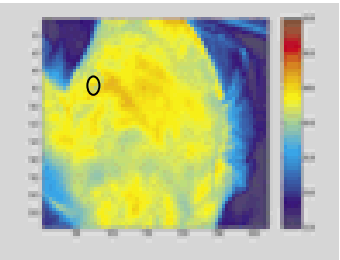

(g) 被験者 7

(g) Subject 7

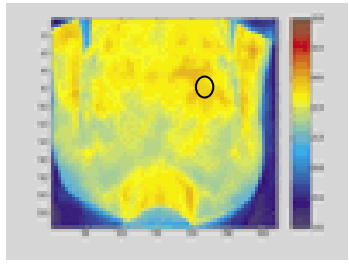

(d) 被験者 4

(d) Subject 4

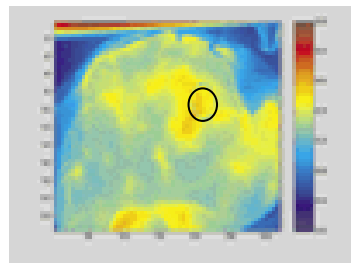

(h) 被験者 8

(h) Subject 8

図 7 加熱 1 分後の各被験者の熱画像

Fig.7 IR image of subjects after heating $1 \mathrm{~min}$.

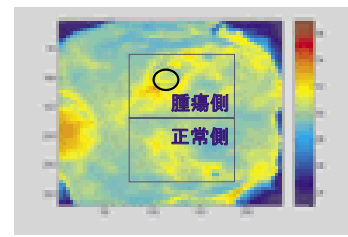

図 8 パーセントヒストグラムの領域

Fig.8 Analysis region of percent histogram.

して, 腫瘍部周辺の温度差が体表面付近の豊富な血管により埋 没してしまい, その結果, 左右温度パターンの違いが分かりにく くなっている.もう 1 つ, 腫瘍の組織型が非浸潤性乳管癌であ ることが原因として考えられ，この場合腫瘍は小さいことが多 く, 血管新生も浸潤性の乳癌に比べて少ないため, 左右差の無 い温度パターンとなったと考えられる。

図 8 のように体表面を左右半分に分けて腫瘍部のある側とない 側で左右対称に同じ面積をとり, その領域における温度の頻度 
数を規格化しパーセントとして表し, 図 6 と図 7 において左右差が 顕著であった被験者 2 と, 左右差の見られなかった被験者 3 を代表 として加熱直前と加熱 1 分後のパーセントヒストグラムを図 9 およ び図 10 に示す. 横軸は温度, 縦軸は各温度のパーセント頻度数を 示す。一方，被験者 7 の場合，横に寝ている状態で撮影されたため 左右差を求めることができなかった.

図 9 に被験者 2 のパーセントヒストグラムを示す. 同図 (a) は加 熱直前, 同図 (b) は加熱 1 分後のパーセントヒストグラムを示す. 加熱直前では, 正常側と比べ腫瘍側のヒストグラムの分布型が広 く，腫瘍側の最頻值も高温側にシフトしていることがわかる．そ して加熱 1 分後では, 加熱直前のヒストグラムと比心゙, 腫瘍側お よび正常側の両方の最頻值が高温側にシフトしていることがわか る.さらに，加熱することで腫瘍側の分布型が平坦になり，正常 側との分布型の差がより明確になっていることがわかる.

図 10 に被験者 3 のパーセントヒストグラムを示す. 同図 (a) は加 熱直前, 同図 (b) は加熱 1 分後のパーセントヒストグラムを示す. 加熱直前と加熱 1 分後では, 図 6 と図 7 と同様に腫瘍側と正常側の ヒストグラムに優位差はみられなかった。

表 2 に加熱直前, 加熱 1 分後, 加熱 2 分後, 加熱 8 分後の時点に おける各被験者のヒストグラムの高温側の上位 $15 \%$ の平均温度を示 寸. 被験者 1 と被験者 3 は, 加熱直前と加熱後における腫瘍側と正 常側の温度差がほとんど見られず，これは図 6 と図 7 の結果および 図 9 と図 10 の結果と一致している. 被験者 2 , 被験者 4 , そして被 験者 8 は, 加熱直前から腫瘍側が正常組織側より温度が高いことが よく見られている. 被験者 5 と被験者 6 は, 加熱直前には腫瘍と正 常組織側の温度差が余り見られないが, 加熱 1 分後および加熱 2 分 後には温度差がみられており, 腫瘍側が正常組織側より温度が高 いことがわかる. しかし加熱 8 分後の上位 $15 \%$ の平均温度では腫瘍 側と正常側の温度差に個人差があり，2 分間までの短時間の加熱の 方が検查には有用であるといえ, 検査時間の短縮が期待される.

上記の結果から腫瘍側と正常組織側には熱分布の違いがあり, 腫瘍側のヒストグラムの分布型が正常組織側より広がっているこ とに基づき各被験者(被験者 7 は除外)の加熱直前と加熱 1 分後にお ける腫瘍側と正常組織側のヒストグラムの標準偏差を求めて表 3 に 示す. 被験者 3 以外は, 加熱直前と加熱 1 分後における腫瘍側の標 準偏差が正常組織側より高いことがわかる.

次に, 加熱前後での単位入射エネルギーあたりの温度変化につ いて検討する. FIR ヒータの放射エネルギーを 1 とすると, 体表面 を介して流入するエネルギーは組織で吸収されるエネルギー $\alpha$, 組 織を透過するエネルギー $\tau$, 体表面で反射されるエネルギー $\rho$ の間 にはエネルギー保存法則が成立し，以下の式が導かれる。

$$
\rho+\alpha+\tau=1 \quad \cdots \cdots \cdots \cdots \cdots \cdots \cdots \cdots \cdots \cdots \cdots \cdots \cdots \cdots \cdots
$$

なお十分な厚さを持っている生体組織の場合, 遠赤外線の波長 帯域では $\tau=0$ であり, 一般的に放射率 $\varepsilon=\alpha$ が成立するから ${ }^{8)}$, 以 下の式が導かれる.

$$
\rho=1-\varepsilon
$$

一般的にヒトの皮膚の放射率 $\varepsilon$ は約 0.98 であり, 反射率 $\rho$ は 0.02 程 度になる。

加熱中に測定される熱画像には図 11 のように体表面の真の温度 (TS ) に加えて, 皮膚表面から反射された FIR ヒータの放射エネルギ 一 $(2 \%)$ になるノイズ分 $(d T r)$ が含まれている. そのため, 測定中の 体表面温度は $T_{S}+d T r$ となり, ここにノイズ分として加算される $d T r$ は測定部位に入射する FIR ヒータの放射エネルギーに比例した 值となる. 従って, FIR ヒータによる加熱過程において, $\mathrm{d} T \mathrm{~s} / \mathrm{d} T \mathrm{r}$ を
計算することにより，各測定部位に届いた FIR ヒータからの入射 エネルギーで正規化した組織の温度変化分を求めることができ る. 図 12 に加熱 1 分後における $d T_{S} / d T r$ の計算例を示す.ここで 加熱直前の体表面の温度を $T \mathrm{~S}_{0}$, 加熱して 1 分間経過したときの温 度を $T \mathrm{~S}_{1}+\mathrm{d} T \mathrm{r}_{1}$, その直後 FIR ヒータを外して測定した温度を $T \mathrm{~S}_{1}{ }^{\prime}$ とすると以下の式が成立する. なお，加熱停止直前に $T \mathrm{~s}_{1}{ }^{\prime}$ ， 加熱停止直後に $T \mathrm{~S}_{1}$ を測定することで, 対象物の温度上昇および 低下を無視できるとして $T_{\mathrm{S}_{1}{ }^{\prime}}=T \mathrm{~S}_{1}$ と近似した。

$$
\begin{aligned}
d T_{S} / d T r & =\left(T_{S_{1}{ }^{\prime}}-T S_{0}\right) /\left(\left(T \mathrm{~s}_{1}+\mathrm{d} T \mathrm{~T}_{1}\right)-T \mathrm{~s}_{1}{ }^{\prime}\right) \\
& =\left(T \mathrm{~s}_{1}{ }^{\prime}-T \mathrm{~S}_{0}\right) / d T_{1} \ldots \ldots \ldots \ldots \ldots \ldots
\end{aligned}
$$

図 13 に腫瘍部位と, 腫瘍部周りの血管部位を解析対象として, 各被験者の FIR ヒータによる加熱 1 分後, 2 分後の各部位におけ る単位放射エネルギーあたりの組織の温度変化分 $\left(d T_{S} / d T r\right)$ を示 す。このとき，それぞれの領域の $d T_{S} / d T r$ 值は測定点近傍の約 60〜160 画素（被験者の腫瘍部の大きさに合わせて選択画素数を 変えている）で空間平均を行った温度から計算された。横軸は測 定部位, 縦軸は $d T_{S} / d T r$ 值, 凡例は積算加熱時間を示す. 図 10 (c) の被験者 3 以外は, 加熱 1 分の時点における血管部位の $d T_{S} / d T r$ 值が他の部位と比べ高いことがわかる. 被験者 3 の場 合, 加熱 1 分と 2 分の時点における血管部位と腫瘍部位の $d T_{S} / d T r$ の差はほとんどなく, これは図 6 の加熱 1 分後の熱画像 の温度パターンの違いがない結果と一致している. 生体組織と 比べて血管は数百倍の熱量の輸送能力があるため ${ }^{5)}$, 周辺組織で 暖められた血液が血管に流入し, 短時間に血管の温度が急上昇 したものと考えられる．加熱 2 分を過ぎると逆に血流が豊富な組 織は血流により冷却され, 一定温度に収束していくため, 血管 部位より腫痬部位の $d T_{S} / d T_{T}$ 值が大きい. 以上の結果から腫瘍部 位と血管部位の $d T_{S} / d T_{r}$ 值には違いがあり, 熱画像から腫瘍部と 血管部を自動的に弁別するための重要な判定基準となると考え る.

\section{5. おわりに}

本論文では，天然ゼオライトを放射体とした FIR ヒータを作製 し, この FIR ヒータによる加熱過程を導入したアクティブ・サー モグラフィを構築した，さらに，本検査システムを用いて 8 名の 乳ガン患者のボランティアを対象として, 乳癌検査の可能性を 検討した. その結果, 被験者 8 名中 6 名で加熱前と加熱 1 分後の 熱画像に違いがあること, 腫瘍のある体側の温度が高いことを 確認した。体表面の温度を定量的に解析した結果, 加熱直前の 左右温度差がほとんどない被験者は 8 名中 3 名であったが， 1 分 間または 2 分間の加熱により 8 名中 6 名の被験者において腫瘍側 の温度が正常側の温度より高くなることを見いだした. 加熱 1 分 後と加熱 2 分後の腫瘍部位および血管部位の $d T_{S} / d T_{\mathrm{r}}$ 特性には 違いがあり，この知見は熱画像から腫瘍部位と血管部位を自動 的に弁別するための重要な判定基準となると考える. また，加 熱 8 分後には各組織における特徵的な熱画像の差異が消失してし まうことから，検查では加熱初期における熱画像の過渡的な変 化が重要であること, さらに検查時間の短縮化が可能であるこ となどがわかった。一方, 初期の病期 Iおよび非浸潤性乳管癌の 患者の例では明確な差異を示すことができないとの問題点も明 らかとなった。

アクティブ・サーモグラフィは非侵襲・非接触であり，放射線 による被爆，検査時の痛みもないため，放射線シールド設備のな 


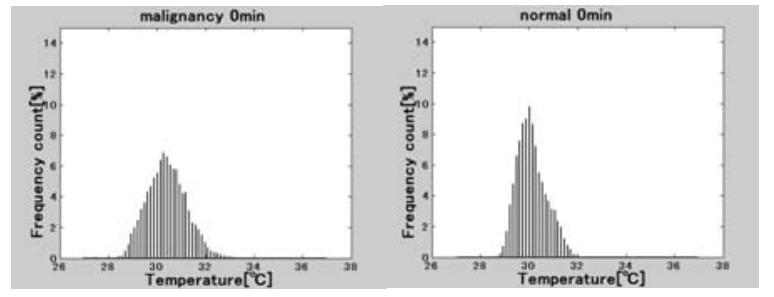

（a）被験者 2 (加熱直前)

(a) Subject 2(just before heating)

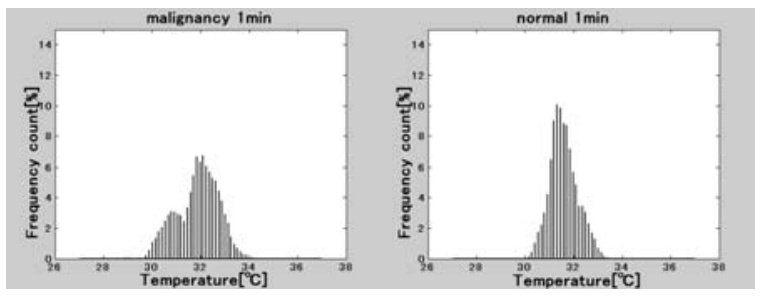

（b）被験者 2 (加熱 1 分後)

(b) Subject 2(after heating $1 \mathrm{~min}$ )

図 9 被験者 2 の熱画像のパーセントヒストグラム

Fig.9 \% histogram of thermal image of subject 2.

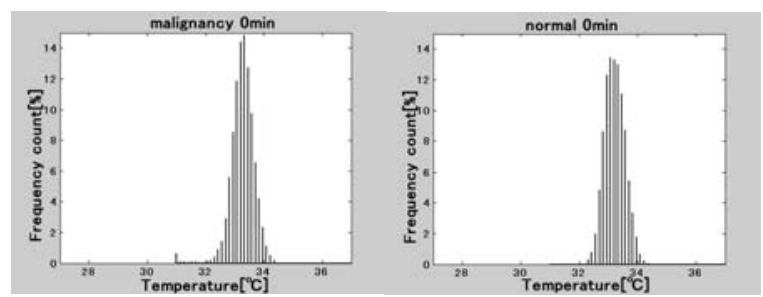

（c）被験者 3 (加熱直前)

(c) Subject 3(just before heating)

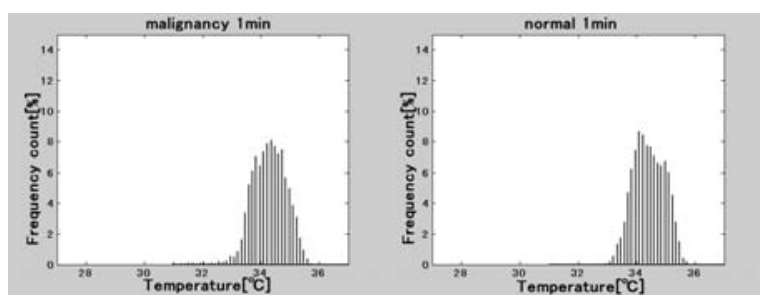

(d) 被験者 3 (加熱 1 分後)

(d) Subject 3(after heating $1 \mathrm{~min}$ )

図 10 被験者 3 の熱画像のパーセントヒストグラム

Fig.10\% histogram of thermal image of subject 3 .

表 2 腫瘍と正常部位における上位 15\%の平均温度

Table 2 Average temperature of top 15\% in malignancy and normal tissue regions.

\begin{tabular}{|c|c|c|c|c|c|c|c|c|}
\hline \multirow{2}{*}{ 被験者 } & \multicolumn{2}{|c|}{ 加熱直前 } & \multicolumn{2}{|c|}{ 加熱 1 分後 } & \multicolumn{2}{|c|}{ 加熱 2 分後 } & \multicolumn{2}{|c|}{ 加熱 8 分後 } \\
\hline & 腫瘍 & 正常 & 腫瘍 & 正常 & 腫瘍 & 正常 & 腫瘍 & 正常 \\
\hline 被験者 1 & $32.2^{\circ} \mathrm{C}$ & $32.3^{\circ} \mathrm{C}$ & $33.2^{\circ} \mathrm{C}$ & $33.3^{\circ} \mathrm{C}$ & $33.6^{\circ} \mathrm{C}$ & $33.5^{\circ} \mathrm{C}$ & $35.1^{\circ} \mathrm{C}$ & $35.6^{\circ} \mathrm{C}$ \\
\hline 被験者 2 & $33.3^{\circ} \mathrm{C}$ & $31.8^{\circ} \mathrm{C}$ & $34.0^{\circ} \mathrm{C}$ & $33.3^{\circ} \mathrm{C}$ & $34.1^{\circ} \mathrm{C}$ & $33.8^{\circ} \mathrm{C}$ & $36.2^{\circ} \mathrm{C}$ & $35.8^{\circ} \mathrm{C}$ \\
\hline 被験者 3 & $34.2^{\circ} \mathrm{C}$ & $34.4^{\circ} \mathrm{C}$ & $35.4^{\circ} \mathrm{C}$ & $35.6^{\circ} \mathrm{C}$ & $35.4^{\circ} \mathrm{C}$ & $35.4^{\circ} \mathrm{C}$ & $36.3^{\circ} \mathrm{C}$ & $36.9^{\circ} \mathrm{C}$ \\
\hline 被験者 4 & $33.7^{\circ} \mathrm{C}$ & $32.9^{\circ} \mathrm{C}$ & $34.0^{\circ} \mathrm{C}$ & $33.6^{\circ} \mathrm{C}$ & $34.8^{\circ} \mathrm{C}$ & $34.0^{\circ} \mathrm{C}$ & $37.1^{\circ} \mathrm{C}$ & $36.4^{\circ} \mathrm{C}$ \\
\hline 被験者 5 & $31.8^{\circ} \mathrm{C}$ & $31.7^{\circ} \mathrm{C}$ & $33.2^{\circ} \mathrm{C}$ & $32.6^{\circ} \mathrm{C}$ & $34.1^{\circ} \mathrm{C}$ & $33.7^{\circ} \mathrm{C}$ & $35.9^{\circ} \mathrm{C}$ & $36.2^{\circ} \mathrm{C}$ \\
\hline 被験者 6 & $35.6{ }^{\circ} \mathrm{C}$ & $35.3^{\circ} \mathrm{C}$ & $37.1^{\circ} \mathrm{C}$ & $36.0^{\circ} \mathrm{C}$ & $37.5^{\circ} \mathrm{C}$ & $36.4^{\circ} \mathrm{C}$ & $37.9^{\circ} \mathrm{C}$ & $37.7^{\circ} \mathrm{C}$ \\
\hline 被験者 7 & - & - & - & - & - & - & - & - \\
\hline 被験者 8 & $33.0^{\circ} \mathrm{C}$ & $32.3^{\circ} \mathrm{C}$ & $33.7^{\circ} \mathrm{C}$ & $33.0^{\circ} \mathrm{C}$ & $34.2^{\circ} \mathrm{C}$ & $33.8^{\circ} \mathrm{C}$ & $36.5^{\circ} \mathrm{C}$ & $36.4^{\circ} \mathrm{C}$ \\
\hline
\end{tabular}

表 3 腫瘍側と正常組織側おけるヒストグラムの標準偏差

Table 3 Standard deviation of \%histogram in malignancy and normal tissue parts.

\begin{tabular}{|c|c|c|c|c|}
\hline \multirow{2}{*}{ 被験者 } & \multicolumn{2}{|c|}{ 加熱直前 } & \multicolumn{2}{c|}{ 加熱 1 分後 } \\
\cline { 2 - 5 } & 正常側 & 腫瘍側 & 正常側 & 腫瘍側 \\
\hline 被験者 1 & 0.83 & 0.94 & 0.75 & 0.84 \\
\hline 被験者 2 & 0.67 & 0.79 & 0.65 & 0.81 \\
\hline 被験者 3 & 0.99 & 1.01 & 0.77 & 0.78 \\
\hline 被験者 4 & 0.80 & 0.89 & 0.73 & 0.78 \\
\hline 被験者 5 & 0.65 & 0.84 & 0.57 & 0.71 \\
\hline 被験者 6 & 0.90 & 1.00 & 0.84 & 0.87 \\
\hline 被験者 7 & - & - & - & - \\
\hline 被験者 8 & 0.69 & 0.82 & 0.66 & 0.80 \\
\hline
\end{tabular}




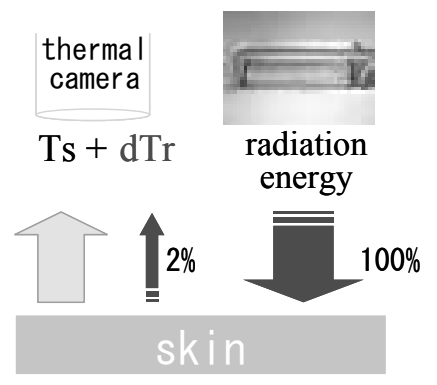

図 11 加熱中に計測される体表面の温度

Fig.11 Temperature of Body Surface measured in Heating.

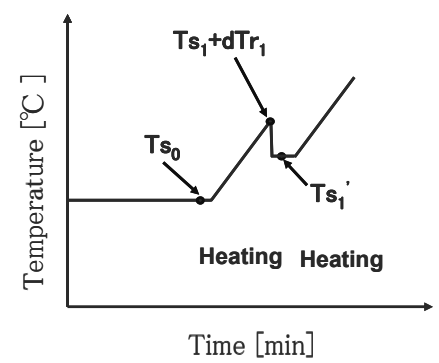

図 12 加熱 1 分後の dTs/dTr の計算例

Fig.12 Example of dTs/dTr calculation after Heating $1 \mathrm{~min}$.

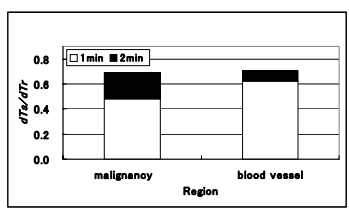

(a) 被験者 1

(a) Subject 1

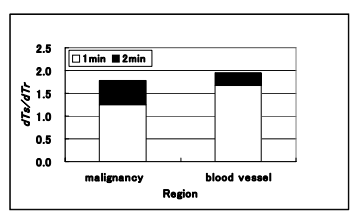

(b) 被験者 2

(b) Subject 2

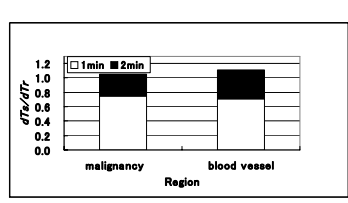

(c) 被験者 3

(c) Subject 3

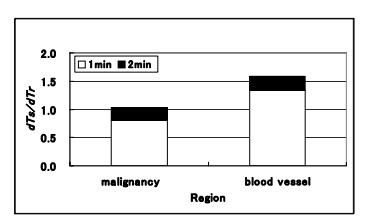

（d）被験者 4

(d) Subject 4

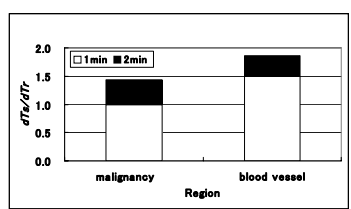

（e）被験者 5

(e) Subject 5

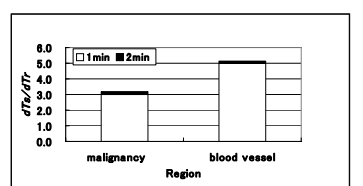

（f）被験者 6

(f) Subject 6

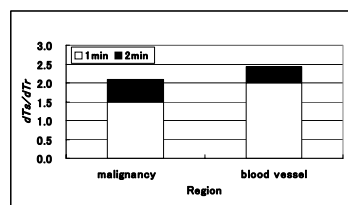

（g）被験者 7

(g) Subject 7

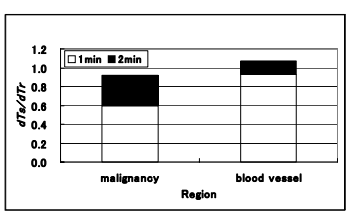

(h) 被験者 8

(g) Subject 8

図 $13 d T s / d T r$ 特性

Fig.13 Property of $d T s / d T r$. 
（6）吾妻辰則, 水戸部一孝, 吉村昇:天然ゼオライトによる遠赤 外線放射体の開発と生体加熱効果に関寸る研究, 平成 14 年 度電気関係学会東北支部連合大会予稿集，p. 201（2002）。

（7）水戸部一孝, 尹鍾賢, 片寄喜久, 小川純一, 吉村昇:FIR ヒー 夕を用いたアクティブ・サーモグラフィ構築の基礎的研究, 照明学会誌論文号, Vol.88, No. 8A, pp. 529-532 (2004).

（8）赤外線技術研究会:赤外線工学，オーム社（1991）.

（受付日 2005 年 6 月 2 日/ 採録日 2006 年 4 月 7 日 )

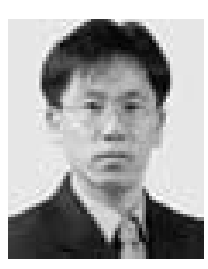

尹 鍾賢 (非会員)

秋田大学工学資源学部電気電子工学科

干010-8504 秋田市手形学園町 $1-1$

1973.4 .12 生. 2001 年 韓国仁荷大学大学院電気 工学科修士修了. 2006 年 秋田大学大学院工学資 源学研究科博士後期課程修了. 現在、秋田大学工学 資源学部研究補助員. 電気学会会員, 博士(工学).

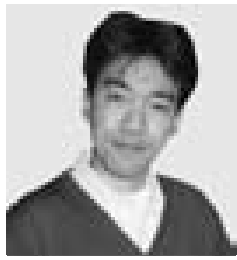

水戸部 一孝 (非会員)

秋田大学工学資源学部電気電子工学科

T010-8504 秋田市手形学園町 $1-1$

1967.10 .12 生. 1996 年北海道大学大学院工学研 究科修了, 同年秋田大学鉱山学部助手, 1998 年 同大学講師, 現在に至る。2002〜03 年 Massachusetts Institute of Technology 客員研究員. IEEE, 電気 学会等会員. 博士(工学).

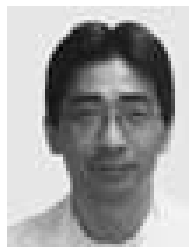

片寄 喜久（非会員）

秋田大学医学部外科学講座呼吸器外科学分野

于010-8543 秋田市本道 $1-1-1$

1964.6 .2 生. 1990 年秋田大学医学部卒業. 1996 年秋田大学医学部助手. 1996 98 年ペンシルヴェ ニア州立大学留学. 1992 年秋田大学医学部助手 現在に至る. 日本乳癌学会 認定医・評議員, 日本外科学会 専門医, 日本消化器外科 認定医など.

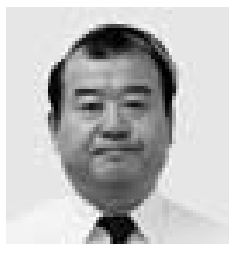

小川 純一 (非会員)

秋田大学医学部外科学講座呼吸器外科学分野

于010-8543 秋田市本道 $1-1-1$

1947.8.20 生. 1973 年慶應大学医学部卒業, 1976 年慶應大学医学部外科学, 1983 年東海大学第一 外科講師, 1994 年東海大学第一外科助教授, 1997 年秋田大学第二外科教授, 現在に至る. 日本呼吸器外科学会 専 門医・評議員, 日本胸部外科学会 指導医・評議員, 日本外科学会 指 導医・評議員など. 医学博士.

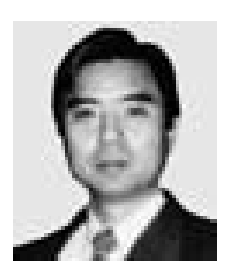

吉村 昇（正会員）

秋田大学工学資源学部電気電子工学科

干 010-8504 秋田市手形学園町 1-1

1943 年生. 秋田大学大学院電気工学専攻修士課 程修了，現在，秋田大学工学資源学部教授・評

議員. 1984 年電気学会論文賞, 1993 年オーム 技術賞受賞，電子・電気材料工学 (培風館)，バ イオ電磁気工学 (サイエンスフォーラム) 等著作. IEEE, 電気 学会等会員. 工学博士.

学学榑土。 